ORIGINAL ARTICLE

PRACA ORYGINALNA

\title{
INVESTIGATION OF THE INFLUENCE OF THROMBOPHILIC GENES POLYMORPHISM, INCLUDING SERPIN 1 (PAI-I), FII, PROTHROMBIN AND ITGB3-B INTEGRIN, ON THE FREQUENCY OF STROKE IN ASSOCIATION WITH CONTROLLABLE RISK FACTORS FOR ITS OCCURRENCE
}

DOI: 10.36740/WLek202003112

\author{
Mikhail M. Oros ${ }^{1}$, Vitaly V. Lutz ${ }^{2}$, Andrukh H. Pavlo ${ }^{3}$, Andrii D. Sitkar ${ }^{4}$ \\ 'REGIONAL CENTER OF NEUROLOGY AND NEUROSURGERY, UZHHOROD NATIONAL UNIVERSITY, UZHHOROD, UKRAINE \\ 2DEPARTMENT OF NEUROLOGY, MUKACHEVO CENTRAL DISTRICT HOSPITAL, MUKACHEVO, UKRAINE \\ ${ }^{3}$ KHARKIV MEDICAL ACADEMY OF POSTGRADUATE EDUCATION, KHARKIV, UKRAINE \\ 4DEPARTMENT OF NEUROLOGY, MUKACHEVO CENTRAL DISTRICT HOSPITAL, MUKACHEVO, UKRAINE
}

\begin{abstract}
The aim is the analysis of the relationship between the polymorphism of thrombophilic genes, in particular Serpin 1 (PAI-1), F2-prothrombin and ITGB3- $\beta$ integrin, and the incidence of stroke, as well as the study of factor effects of this polymorphism in association with controlled risk factors (hypertonic disease, smoking, alcohol consumption, diabetes mellitus, obesity, atrial fibrillation).

Materials and methods: A total of 134 patients were examined (men accounted for 44.8\%, women 55.2\%, average age 62.5 \pm 2.1 ). The statistical analysis was carried out using the following criteria: X2-Pearson, Fisher's exact criterion (reversible), Chuprov's coefficient of conjugation and dispersion analysis (alternative complex).

Results: The relationship between the frequency of a specific allele of thrombophilia and the incidence of stroke is absent. The reason for such results can be a significant effect of random factors (hypertension, diabetes ...), a significant variability of risk factors, their different frequency in groups (inter- and intra-group differences), a significant (95\%) total effect of these factors.

Conclusions:Identification of biochemical or genetic markers of thrombophilic conditions, including polymorphism of the hemostasis system genes, will significantly increase the possibility of adequate pathogenetic treatment and timely prevention of acute cerebrovascular disorders, especially persons of working age, which has great medical and social importance.
\end{abstract}

KEY WORDS: stroke, gene, polymorphism, risk factors, thrombophilia

Wiad Lek. 2020;73(3):471-477

\section{INTRODUCTION}

Among the urgent and priority problems of modern neurology strokes firmly hold the leading position due to its large prevalence, high mortality and disability of population in economically developed countries and large financial costs of treatment and rehabilitation [ 1 , 2]. Every year, more than 20 million cases of stroke are registered in the world, making it the second leading cause of death and the third in terms of disability of adults [3]. Among the neurological diseases, cerebral stroke is one of the most significant medical and social problems in most countries of the world, including in Ukraine [4]. The high level of mortality and disability of people who have suffered a stroke, brings the problem far beyond purely medical issues, makes it socially significant on a national scale, strengthens the negative demographic situation in the country.

In recent decades, many studies have been devoted to molecular genetic analysis of ischemic stroke in different populations [5]. These same studies have shown that in the vast majority of cases (about 90\%) ischemic stroke is a multifactorial disease in the development of which, in a variety and complex combinations, lifestyle characteristics, environmental factors and individual genetic characteristics of the organism participate. In recent years, much attention has been paid to the study of the effect of genetic predisposition on the state of the coagulating system of blood [6]. The role of polymorphism in a number of genes has been established, the protein products of which regulate the hemostasis system in the development of vascular pathology $[6,7]$. It is obvious that one can not speak of the dominant role of any one gene. Most likely, we are talking about a variety of very diverse genes, the combined effect of which is involved in the formation of the so-called polygenic propensity to stroke [8].

Over the past 20 years in the literature over 100 humoral, pathological, hereditary-constitutional and social and economic factors of the risk of stroke have been described. 
The most significant of them - age, arterial hypertension, atherosclerosis, heart rhythm disorders, diabetes mellitus, smoking, alcoholism [9].

According to the World Health Organization, more than 300 risk factors for the development of cerebrovascular diseases have been identified. They can be grouped into four categories:

1) The main managed risk factors (high blood pressure, atherosclerosis, smoking, hypodynamia, excess body weight, diabetes mellitus, malnutrition).

2) Other managed risk factors (social status, emotional strain, alcohol or drug abuse).

3) Unfocused risk factors (sex, age, heredity, ethnicity).

4) "New" risk factors (hyperhomocysteinemia, vasculitis, blood coagulation disorder).

One of the topical issues of modern health care is the elucidation of the molecular genetic foundations of the development of cardiovascular diseases. Due to the extraordinary social and medical significance, one of the main subjects of study is a hemostasis system, the functioning of which is one of the leading risk factors for the development of thrombophilic states, including ischemic stroke.

The genes that can lead to ischemic stroke are categorized as: 1) increasing the influence and manifestation of stroke risk factors; 2) affect vascular reactivity, resistance to ischemia and hypoxia. It should also be noted that these categories are not mutually exclusive [10].

Genetic polymorphism is a persistent, unmanageable risk factor. Genetic factors contribute to the development of hypertension, atherosclerosis, hemorheological disorders, diabetes, which are risk factors for stroke, and individual sensitivity to brain ischemia [11]. In more than $1 / 3$ of the cases, the causes of an ischemic stroke remain unclear, so you should think about the presence of genetic predisposition.

The main cause of ischemic stroke is the cerebral artery thrombosis, and thus studying the polymorphism of the genes responsible for the hemostasis is one of the most urgent tasks.

The studies of structural polymorphisms of genes are of great interest that contribute trombophilic states, linking carriage of certain alleles of polymorphic sites of genes and risk of ischemic stroke and progress to identify individuals at increased genetic risk of stroke, improving prognosis and course of cerebrovascular disease $[12,13]$. There are many genes, certain alleles associated with an increased risk of cerebrovascular disease.

In addition, the risk of developing ischemic stroke increases not only under the influence of polymorphism involving a pair of nucleotides, but also when combining the alleles of several genes, i.e. has a polygenic hereditary predisposition. Often, there is more than one factor of the prothrombotic state. Hereditary thrombophilia can play an important role in the pathogenesis of ischemic stroke due to synergistic, cumulative effects, hereditary effects and some external factors such as smoking, contraceptive use, diabetes, hyperlipidemia, and hypertension. It should be noted that there are no clear guidelines for the treatment of patients with ischemic stroke in the case of hereditary thrombophilia nowadays [14].
Research of polymorphism of genes as a factor of genetic predisposition to various human diseases opens up new opportunities in identifying risk and choosing optimal therapy for each patient [15]. Detection of genetic determinism of ischemic stroke allows preventably determine the risk factors for its occurrence [16]. However, the contribution of mutational damage to genes coding for blood coagulation factors in increasing the risk of developing ischemic stroke has not been definitely defined for the present.

\section{THE AIM}

The aim of the study is the analysis of the relationship between the polymorphism of thrombophilic genes, in particular Serpin 1 (PAI-I), FII-prothrombin and ITGB3- $\beta$ integrin, and the incidence of stroke, as well as the study of factor effects of this polymorphism in association with controlled risk factors (hypertonic disease, smoking, alcohol consumption, diabetes mellitus, obesity, atrial fibrillation).

\section{MATERIALS AND METHODS}

A total of 134 patients were examined in Mukachevo CRH (men accounted for $44.8 \%$, women $55.2 \%$, average age 62.5 \pm 2.1 years, urban population $67.2 \%$, rural $32.8 \%$ ) for the presence of a certain allele of the following genes in them: Serpin 1 (PAI-I), FII-prothrombin, ITGB3- $\beta$ integrin. Also, a survey was conducted on the presence of risk factors for stroke: hypertension, smoking, alcohol, obesity, atrial fibrillation, diabetes, stroke in direct relatives.

The study was carried out with the consent of the volunteers, and the methodology met the Helsinki Declaration of 1975 and its review in 1983. All participants of the study got acquainted and signed the form of informed consent, the structure of which corresponded to the officially accepted one.

The statistical analysis was carried out using the following criteria:

1) X2-Pearson: tables $2 \times 2$ (corrected by Yeats); $\chi 2$-Pearson: mxn (arbitrary tables); Fisher's exact criterion (reversible) - for the analysis of the reliability of the relationship between the incidence of stroke and the presence of a definite allele of thrombophilia $[17,18]$;

2) Chuprov's coefficient of conjugation - to assess the strength of the relationship between the above phenomena [19];

3) dispersion analysis (alternative complex) - for analysis of the total factor influence of polymorphism gene and risk factors (hypertonic disease, obesity, diabetes, etc.) on the incidence of stroke [20].

For a critical level of certainty $\alpha=0.05$ was considered.

Statistical processing of the obtained results and data was carried out by using the program of Microsoft Excel 2007 with the introduction into the program of the appropriate algorithms for calculating the statistics used criteria.

\section{RESULTS}

Patients were divided into 3 groups (Table I) for further study of the influence of factors on performance indicators: 
I group: $\mathrm{n}=31$, men $-51.6 \%$, women $-48.4 \%$, average age $56.8 \pm 4,8$ years. Group II: $\mathrm{n}=30$, the proportion of men $-53.3 \%$, women $-46.7 \%$, the average age $-55.8 \pm 4.5$ years. III group: $\mathrm{n}=73$, the proportion of men $-38.4 \%$, women $-61.6 \%$, the average age $-58.4 \pm 3.0$ years. And the group was considered a control group.

In this sample of patients, the polymorphism of the following genes was investigated (Figure 1):

1) FII-prothrombin (factor II blood clotting) FII: 20210 G> A; normal allele G / G; allele of risk G / A, A / A; frequency in the population $-2-5 \%$, inheritance by autosomal dominant type.

2) Serpin 1 (PAI-I) - antagonist of the tissue plasminogen activator PAI-I: -675 5G> 4G; normal allele 5G / 5G; allele risk $5 \mathrm{G} / 4 \mathrm{G}, 4 \mathrm{G} / 4 \mathrm{G}$; the frequency is $5-8 \%$.

3) ITGB3- $\beta$ integrin (platelet fibrinogen receptor) ITGB3: $1565 \mathrm{~T}>\mathrm{C}$; normal allele T / T; allele of risk C / T, C / $C$; frequency $-20-30 \%$.

According to the results of genetic research, the highest frequency of alleles risk, as well as the variability of the trait, was observed for the Serpin gene $1-76.9 \%$ (40.3\% heterozygous, $36.6 \%$ homozygous), the lowest relative to the F2-prothrombin gene $-1.6 \%$.

For the analysis of the relationship between the presence of the pathological allele of thrombophilia and the occurrence of a stroke, conjugacy tables were compiled in various combinations. According to the results of calculations (Table II), it can be concluded that there is no relationship between the polymorphism of the studied genes and the frequency of stroke ( $p>0.05)$, regardless of which type of conjugation table was created and used for further analysis.

Note: grouping vertically for a particular gene; for the coefficient of Chuprov's conjugation the interconnection power was estimated on the Chaddock scale.

To evaluate the effect of the factor (the presence of a certain allele of the thrombophilia gene) on stroke frequency, an analysis of variance (an alternative complex) has been used. For this purpose, a special table was constructed (Table III): horizontally - variants of the Serpin 1 alleles (PAI-1) (factor A), vertically - variants of the alleles of the ITGB3- $\beta$ gene integrin (factor B), in cells - stroke rate (in the numerator - the number of cases of stroke, in the denominator - the total number of cases).

According to the results of the calculations, the total effect of the polymorphism of the genes SIRPIN 1 (PAI-1) and ITGB3- $\beta$ integrin on the frequency of stroke is $5 \%$, the effect of uncorrected random factors $-95 \%$. The calculated value of $\mathrm{F}=0.73(\mathrm{P}=0.665)$. The calculated value of $\mathrm{F}$ for factor $\mathrm{A}$ is $0.13(\mathrm{P}=0.878)$, for factor $\mathrm{B}-0.23(\mathrm{P}=0.795)$, for a combination of factors $\mathrm{A}$ and $\mathrm{B}-1.27(\mathrm{P}=0.286)$. It follows that the influence of the polymorphism of the above genes alone or their combination on the incidence of stroke is not significant ( $\mathrm{p}>0.05)$.

Similar calculations using the alternative complex of dispersion analysis were performed between the polymorphism of the Sperpin 1 (PAI-1) and the ITGB3- $\beta$ integrin (factor A) genes on the one hand and the frequency of controlled stroke risk factors (hypertonic disease, smok- ing, alcohol use, obesity, and fibrillation atrium, diabetes mellitus, permanent residence) (Figure 2) in the sample under study (factor B). The polymorphism of the FII-prothrombin gene was not included in the calculations due to the low frequency of the allele risk (1.6\%).

According to the statistical analysis, the polymorphism of the genes of thrombophilia alone does not affect the incidence of stroke, but a statistically significant total effect of the polymorphic variants of the Sperpin 1 (PAI-1) and ITGB3- $\beta$ integrin genes in combination with hypertension, diabetes mellitus and place of residence has been found (Table IV).

\section{DISCUSSION}

Characteristics of the studied genes are shown below.

I. Polymorphism of the 20210G $>$ A prothrombin gene (FII). The prothrombin gene is localized on the 11th chromosome (llpll-q12). It codes the amino acid sequence of the prothrombin protein. Prothrombin, or coagulation factor II, is one of the main components of the blood coagulation system. As a result of its enzymatic cleavage, thrombin is formed. This reaction is the first stage in the formation of a blood clot.

The polymorphism of the $20210 \mathrm{G}>\mathrm{A}$ prothrombin gene is the most significant and most discussed in the literature. This polymorphous variant of the prothrombin gene is a nucleotide substitution of the guanine $(G)$ nitrogenous base $(G)$ on adenine (A) at position 20210 in the third non-translated region of the gene, which leads, in the case of variant $A$, to high gene expression and, consequently, to increase the level of prothrombin in 1, 5-2 times. The excess production of prothrombin due to polymorphism contributes to increased risk of thrombophilia, which is a risk factor for developing myocardial infarction, various thromboses, including thromboembolism of the pulmonary artery, which often has a lethal end. An unfavorable variant of polymorphism (A) is inherited by an autosomal dominant type. This means that an increased risk of thrombophilia occurs even in a heterozygous form of polymorphism (G/A). The presence of the $20210 \mathrm{G}>$ A polymorphism of the prothrombin gene in a homozygous or heterozygous form significantly (in 3 and more times, and against the background of smoking - 40 and more times) increases the risk of venous thrombosis, including thrombosis of the vessels of the brain and heart, especially at younger ages $[21,22]$.

Heterozygous carriers of this polymorphic gene variant are 2-5\% of Europeans in the general population and 6.2\% of all patients with venous thrombosis [21]. Homozygous variant is extremely rare [23].

Women with non-pregnancy and premature placental abnormalities have mutation in $7-8 \%$ of cases [24]. When combined with the Leiden mutation, the risk of thrombosis increases by almost 100 times [25]. The mutation was described in 1996. Its main clinical feature is the constantly high level of prothrombin in blood plasma ( $87 \%$ of carriers have its excess $115 \%$ ). The polymorphism of the $20210 \mathrm{G}>$ A prothrombin gene of younger patients is associated with a high risk of thrombosis not only in the peripheral veins 

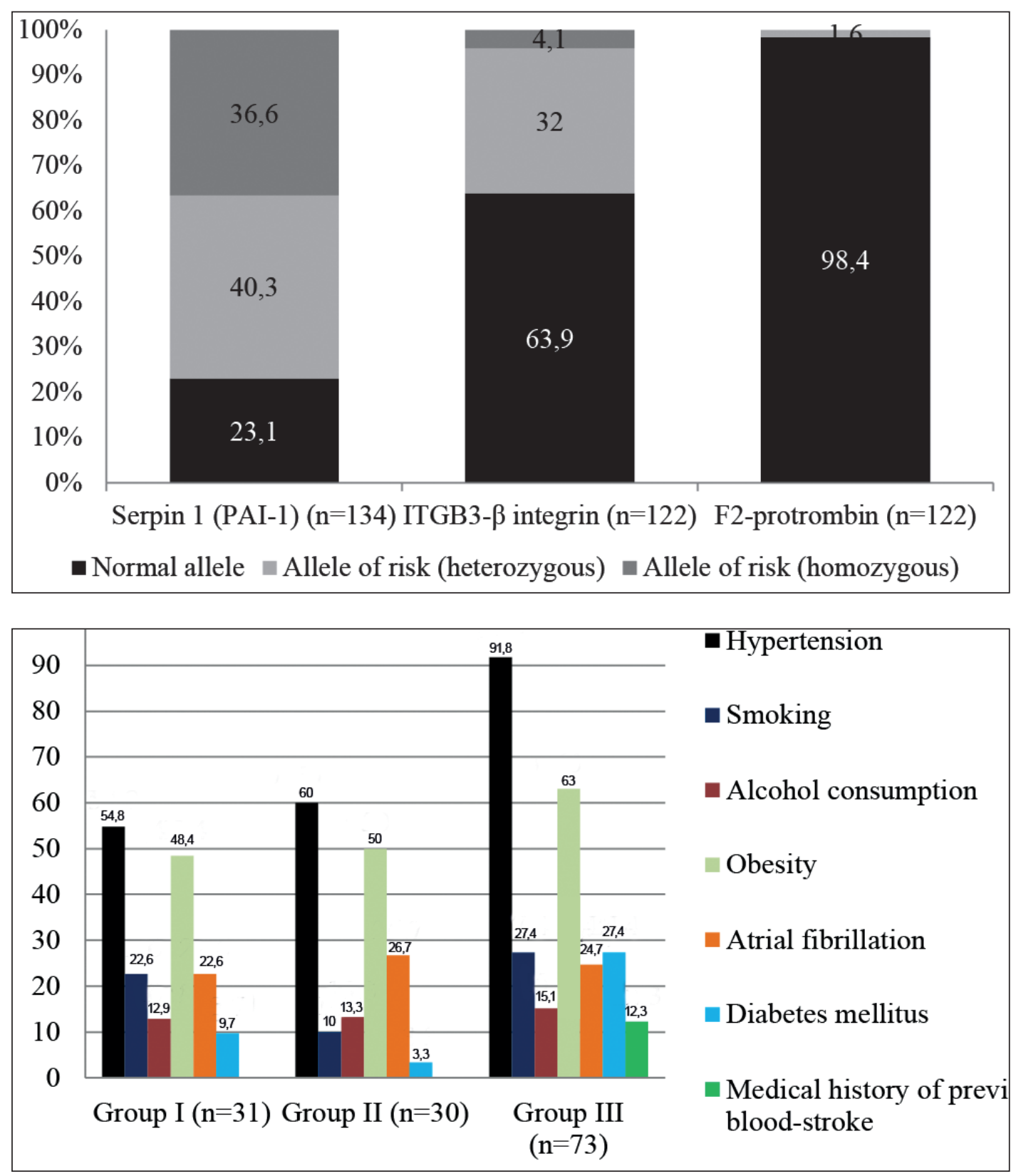

Fig. 1. Frequencies (\%) of certain alleles for the whole sample of study.
Fig. 2. Specific gravity (\%) of people with a risk factor of stroke (in groups). and veins of the brain, but also in arteries with the development of ischemic stroke and coronary heart disease [26].

II. Polymorphism -675 5G \& gt; 4G Plasminogen Activator Inhibitor Type I (PAI-I, SERPINE 1). The basis of the pathogenesis of most thrombophilic states is the decrease in the activity of the fibrinolytic blood system. Therefore, the definition of genetic defects in fibrinolytic potential is an important stage in the diagnosis of hereditary thrombophilia [23].

One of the reasons for the reduction in fibrinolytic activity of the blood is a violation of the conversion of plasminogen into plasmin, due to a decrease in the activity of plasminogen activators. This condition can be either genetically determined, or caused by various acquired states, but most often due to their combination.

Recently, more and more attention has been paid to the role of a type I plasminogen activator (PAI-I) inhibitor in reducing the fibrinolytic potential of plasma.
The type I plasminogen gene is localized on the 7q22.1 chromosome, encoding the protein, an endothelial inhibitor of Plasminogen-1 activator (IAP-1) belonging to the Serpin family. This protein suppresses the work of the tissue plasminogen activator and urokinase, whose function is to activate the conversion of plasminogen to plasma that cleaves fibrin of the blood clots. Thus, PAI-I adversely affects fibrinolysis and prevents dissolution of blood clots, thereby increasing the risk of developing various thromboembolism, including arterial thrombosis.

The basis of the polymorphism of the PAI-I gene is the change in the number of guanine repeats in the promoter region of the gene. There are two variants of the gene with a different number of guanine repeats $(G)$ at positions -675 : $5 \mathrm{G}$ and $4 \mathrm{G} .5 \mathrm{G}$ indicates the presence of a sequence of five nitrogen guanine bases. Option $4 \mathrm{G}$ indicates the presence of a sequence of four guanine bases - an unfavorable option, 
Table I. Distribution of patients by groups

\begin{tabular}{ccc}
\hline Group & Patients with stroke & Direct relatives with stroke \\
\hline I & - & - \\
\hline II & - & + \\
\hline III & + & + \\
\hline
\end{tabular}

Table II. Collected data of criterion values of applied statistical methods

\begin{tabular}{|c|c|c|c|}
\hline Criterion & Serpin 1 (PAI-1) & ITGB3- $\beta$ integrin & FIl- prothrombin \\
\hline X2-Pearson: $2 \times 2$ & $0,209(P=0,648)$ & $0,142(P=0,706)$ & $0(P=1)$ \\
\hline x2- Pearson: $2 \times 2$ (with Yates' correction) & $0,063(P=0,802)$ & $0,036(P=0,85)$ & $0,508(P=0,476)$ \\
\hline x2-Pearson: $2 \times 3$ & $0,738(P=0,691)$ & $0,482(P=0,786)$ & - \\
\hline x2-Pearson: $3 \times 3$ & $0,874(P=0,928)$ & $0,624(P=0,96)$ & - \\
\hline Fischer's exact criterion & $P=0,685$ & $P=0,711$ & $P=1$ \\
\hline coefficient of Chuprov's conjugation & $\begin{array}{c}0,04 \text { (weak interconnection } \\
\text { power) }\end{array}$ & $\begin{array}{c}0,034 \text { (weak } \\
\text { interconnection power) }\end{array}$ & 0 \\
\hline
\end{tabular}

Table III. The effect of the factor (the presence of a certain allele of the thrombophilia gene) on stroke frequency

\begin{tabular}{|c|c|c|c|}
\hline Factors $B \downarrow$ i $A \rightarrow$ & $5 \mathrm{G} / 5 \mathrm{G}$ & $5 G / 4 G$ & 4G/4G \\
\hline $\mathrm{T} / \mathrm{T}$ & $a / A$ & $\mathrm{~b} / \mathrm{B}$ & $c / C$ \\
\hline $\mathrm{C} / \mathrm{T}$ & $d / D$ & $\mathrm{e} / \mathrm{E}$ & $f / F$ \\
\hline $\mathrm{C} / \mathrm{C}$ & $g / G$ & $h / H$ & $\mathrm{i} / \mathrm{l}$ \\
\hline
\end{tabular}

Table IV. Criteria values and levels of reliability of the dispersion analysis

\begin{tabular}{cccc}
\hline Gene & Risk factor & F (P) & Share of Total Impact \\
\hline \multirow{2}{*}{ Serpin 1 (PAI-1) } & Hypertension & $5,46(P=0,00014)$ & $17,6 \%$ \\
\cline { 2 - 4 } & Diabetes mellitus & $2,41(P=0,03997)$ & $8,6 \%$ \\
\cline { 2 - 4 } & Place of residence & $2,92(P=0,0157)$ & $10,2 \%$ \\
\cline { 2 - 4 } ITGB3- $\beta$ integrin & Hypertension & $7,59(P=0,00011)$ & $16,2 \%$ \\
& Diabetes mellitus & $3,09(P=0,029914)$ & $7,3 \%$ \\
\cline { 2 - 4 } & Place of residence & $4,22(P=0,007082)$ & $9,7 \%$ \\
\hline
\end{tabular}

which leads to a decrease in fibrinolysis blood activity due to an increase in plasma concentration of IAP-1. This is due to changes in the processes governing the functioning of the PAI-I gene. When there are five guanine repeats in the promoter region, both activators and transcription suppressors can be contacted with it. Therefore, the regulation of such a gene occurs correctly. In the presence of four repetitions guanine coupling suppressor is violated, therefore, reverse regulation does not occur and the basal activity of protein synthesis is increased. In a homozygote in the $4 \mathrm{G}$ allele ( $4 \mathrm{G} /$ $4 \mathrm{G}$ genotype), increasing the concentration of IAP-1 in blood plasma leads to an increased risk of thrombocytopenia, and in pregnancy increases the risk of non-pregnancy and to a complication such as pre-eclampsia - it is associated with intervertebral thrombosis or spiral arteries of the placenta.

Timely detection of this allele will allow adequate prevention and avoidance of complications.

The preferred variant of studied polymorphism in the population is the heterozygous variant $-6755 \mathrm{G} / 4 \mathrm{G}$. In this regard, this polymorphism has no independent diagnostic value, the effect can be evaluated in combination with other factors that lead to the development of pathology (for example, in conjunction with FGB G-455A). The allelic variant $-6754 \mathrm{G}$ is accompanied by greater activity of the gene than $-6755 \mathrm{G}$, which results in a higher concentration of PAI-I and a decrease in the activity of the antiglient system of blood [27]. In the in vitro experiment, it was shown that in the $4 \mathrm{G}$ / 4G homozygote, the basal level of expression of PAI-I was $25-30 \%$ higher than that of the carriers of the $5 \mathrm{G}$ allele [7].

According to a number of studies, the 4G / 4G genotype increases the risk of developing thrombosis by an average of 1.7 times. Increasing RAI-1 increases the risk of coronary syndrome and myocardial infarction [28]. Women with the 4G/4G genotype have an increased risk of developing complications of pregnancy, since suppressed fibrinolysis, which plays an important role in the formation of the mother-placenta-fetus system. What concerns men, this polymorphism increases the risk of coronary thrombosis 5-fold; with coronary artery disease, the 4G / 4G genotype is associated with the development of sudden death. In the presence of variant $4 \mathrm{G}$ in the gene PAI-I and C / T in the gene ITGB3- $\beta$, the average statistical risk of myocardial infarction increases 4.5 times, and for men -6 times $[29,30]$. 
Allele $4 \mathrm{G}$ occurs in $53-61 \%$ of cases in the European population. The prevalence of the homozygous form of this polymorphism in the Europoid populations is 5-8\%.

III. Polymorphism of $1565 \mathrm{~T}>\mathrm{C}$ the fibrinogen platelet receptor gene (ITGB3- $\beta$ ). The gene ITGB3- $\beta$ encodes the protein component of the fibrinogen platelet receptor, beta-3 integrin (GP IIIa). With the participation of this receptor, the interaction of thrombocytes with fibrinogen, which is contained in the plasma of blood, is carried out. As a result, aggregation of thrombocytes is activated and a thrombus is formed.

This polymorphism is based on the replacement of thymine $(\mathrm{T})$ by cytosine (C) at position 1565 of the gene. As a result, the biochemical properties of the GPIIIa protein change, where the amino acid leucine is replaced by proline at position 59 (Leu59Pro).

The polymorphic variant of the ITGB3- $\beta$ gene leads to an increase in platelet aggregation, which increases the risk of thrombotic formation and, consequently, the development of cardiovascular pathology, thromboembolism, as well as early termination of pregnancy due to thrombotic lesions of the placenta. The conducted epidemiological studies have shown the association of the polymorphic variant $1565 \mathrm{~T}>\mathrm{C}$ of the gene ITGB3-in with the development of ischemic stroke, as well as coronary heart disease [30]. An increase in the rate of detection of allele $\mathrm{C}$ of patients with myocardial infarction under the age of 60 was found to be twice as high as in the control group.

When studying polymorphism of $1565 \mathrm{~T}>$ C polymorphism of ITGB3- $\beta$ gene of healthy non-smokers aged 21 to 24 years, it was found that allele $\mathrm{C}$ is associated with increased thrombin generation and an antithrombotic effect of aspirin. For patients with $\mathrm{T} / \mathrm{C}$ and $\mathrm{C} / \mathrm{C}$ genotypes, the effectiveness of this drug as an antiaggregant is reduced.

In addition, the 1565T> C polymorphism of the ITGB3- $\beta$ gene is associated with syndromes of thrombocyte immune destruction, to a greater extent with neonatal thrombocytopenia and alloimmune posttransfusion purpura.

Thus, in the development of ischemic stroke, its genetic determinism plays an important role (especially for young people who do not have other most common risk factors).

\section{CONCLUSIONS}

Thus, the relationship between the frequency of a certain allele of thrombophilia and the incidence of stroke is absent. The reason for such results can be a significant influence of random factors (hypertension, diabetes, ...), significant variability of risk factors, different frequency in groups (inter- and intra-group difference), a significant (95\%) total effect of these factors. The lack of connection in this study may be due to the fact that the pathology of the hemostatic system (thrombophilia) in itself does not significantly affect the incidence of stroke due to the good compensatory mechanisms of the human body for the development of ischemia in this case.

But the significance of the total factor influenceof genes 1 polymorphism (PAI- 1 ) and ITGB3- $\beta$ integrin and such risk factors as diabetes mellitus and hypertension as well as the place of residence should be noted. Since these controlled factors (arterial hypertension and insulin resistance) are components of a metabolic syndrome, which is a "disease of civilization", and the rate of urbanization only increases (the proportion of urban population in the sample was 67.2\%), the study of hereditary pathology of the hemostasis system as unmanaged factor, is rather perverse. It broadens the existing understanding of the heterogeneity of ischemic stroke and consistently confirms the concept of its heterogeneity in mechanisms and causes of occurrence. Identification of biochemical or genetic markers of thrombophilic conditions, including polymorphism of the hemostasis system genes, will significantly increase the possibility of adequate pathogenetic treatment and timely prevention of acute cerebrovascular disorders, especially persons of working age, which has great medical and social importance.

Given that ischemic strokes are multifactorial diseases, in the development of which the complex interaction of various external risk factors plays a part in the presence of a genetic predisposition, the question of which interactions of the acquired and genetic factors, as well as the combination of polymorphic variants of genes lead to the development of arterial thrombosis, determine the features of the course of the acute period of the disease and possible complications, as well as relapses, remains open.

The modern neurologist and scientist need to know the genetic basis of hereditary diseases of the nervous system to a lesser extent than the morphological and physiological patterns of its activity. Further research in the field of medical genetics, neurology and other fundamental disciplines will be the basis of quality treatment and timely prevention of ischemic stroke in combination with thrombophilia.

\section{REFERENCES}

1. Ovsyannikova A.N. Polymorphism of genes of hemostasis system of patients with ischemic stroke of young and middle age [Analysis of polymorphism of hemostasis system genes in the development of acute brain ischemia in young and middle-aged patients]. Dis.Candidate of med. Sciences: Saratov, 2017; p.26. (in Russian).

2. Suslin, Z. A., Piradov M.A., Domashenko M.A. Insult: otsenka problemyi (15 let spustya) [Stroke: Assessment of the Problem (15 Years Later)]. Journal of Neurology and Psychiatry 2014;(No. 11):5-13. (in Russian).

3. Murray C, Lopes A. Measuring the global burden of disease. N. Engl. J. Med.2013;Vol.369: 448-457.

4. Gusev E.I. Insult [Stroke]. M. 2003, p. 3-7. (in Russian)

5. Koltsova E.A. Rol strukturnyih osobennostey genov reninangiotenzinovoy sistemyi, endotelialnoy N0-sintazyi i r53 v razvitii osnovnyih faktorov tserebro-vaskulyarnoy patologii i insulta [The role of structural features of the renin-angiotensin system genes, endothelial N0 synthase and p53 in the development of the main risk factors for cerebrovascular pathology and in the development of brain infarction]. Dis. Candidate of med. sciences M.: 2002. p.124. (in Russian)

6. Lindgren, A. Stroke genetics: a review and update. J. Stroke. 2014;16:114-123.

7. Williams Tan M.-S. et al. Genome - wide association studies in neurology. Transl. Med. 2014;2:124.

8. Illarioshkin S.N. Genetika sosudistyih zabolevaniy mozga. Esse 0 angioedeme [Genetics of vascular diseases of the brain. Essays on angioedema]. Ed. BY. Suslina M.: Atmosphere, 2005. p.341. (in Russian) 
9. Vilensky B. Insult: profilaktika, diagnostika i lechenie [Stroke: prevention, diagnosis and treatment]. St.Pb : Foliant, 2002; p. 397 . (in Russian)

10. Shibilova M.U. Geneticheskie determinantyi ishemicheskogo insulta FGBU "Poliklinika No 1" Prezidenta Rossiyskoy Federatsii [Genetic determinants of ischemic stroke FGBU “Polyclinic № 1" of the President of the Russian Federation]. Journal "Kremlin Medicine" Clinical Herald, No. 3, 2013. (in Russian)

11. Pisov N.V. Trombofiliya: geneticheskie polimorfizmyi i sosudistyie katastrofyi [Thrombophilia: genetic polymorphisms and vascular disasters]. M .: IMA-PRESS, 2013. p. 248, 13. (in Russian)

12. Botto N. et al. Mutatsii genov protromboticheskoy sistemyi yavlyayutsya faktorami riska razvitiya kriptogennyih ishemicheskih tserebrovaskulyarnyih sluchaev u molodyih lyudey s otkryityim ovalnyim oknom [The mutations of the genes of the prothrombotic system are risk factors for the development of cryptogenic ischemic cerebrovascular cases of young people with an open oval window]. Stroke 2008; (in Russian)

13. Frolova S.Yu.Molekulyarno-geneticheskoe issledovanie nasledstvennogo komponenta vospriimchivosti k insultu naseleniya Tomska. [Molecular genetic study of the hereditary component of stroke susceptibility to the population of Tomsk]. Dis. Candidate of med. sciences Tomsk, 2005; p.169. (in Russian)

14. Bogdanov E.I. Ishemicheskiy insult v molodom vozraste [Ischemic stroke at a young age]. Neurological messenger. 2012;2:30-40. (in Russian)

15. Gayfullin R.F., Kravtsova 0.A., Rizvanova F.F. et al. Pediatriya [Pediatrics]. Practical medicine. 2010;6:3-5. (in Russian)

16. Zorilova I.V. Molekulyarno-geneticheskie faktoryi riska trombofilicheskih sostoyaniy pri ishemicheskom insulte u patsientov molodogo vozrasta [Molecular Genetic Risk Factors for Thrombophilic States with Ischemic Stroke of Young Patients: Author's abstract]. Dissertation Candidate of med. sciences 2006, p.4. (in Russian)

17. Glants S. Mediko-biologicheskaya statistika [Medical and Biological Statistics]. Trans. from English - M., Practice, 1998. p. 459 (in Russian)

18. Petri A., Sabin K. Naglyadnaya statistika v meditsine [Visual medical statistics]. / Trans. from English ed. V.P. Leonova. M .: GEOTAR-MEDIA, 2009. p.168. (in Russian)

19. Medic V.A. Statistika zdorovya naseleniya i zdravoohraneniya: uchebnoe posobie [Statistics in medicine and biology: manual]. Sev.zap Department of Russian. acad. Of med. sciences Novgor scientific center; Novgor state University after Yaroslav the Wise. Moscow: Medicine, 2000. (in Russian)

20. Mintser 0.P. at al. Novyie informatsionnyie tehnologii v meditsine [Information Technologies in the Protection of Health and Practical Medicine: Teaching. manual for students of higher ed.]. K.: Higher school, 2003. p.350. (in Ukrainian)

21. Chudej, J., I. Plameňová I. Prothrombin gene 20210A mutation in Slovak population. Vnitr Lek. 2016;4:281- 286.

22. Moussaoui S. et al. Genetic Risk Factors of Venous Thromboembolism in the East Algerian Population Clin Appl Thromb Hemost. 2015. Aug 23.

23. Popa, AV. Vliyanie geneticheskoy trombofilii na tyazhest techeniya gemolitiko-uremicheskogo sindroma u detey [The role of thrombophilia in the development of thrombolytic microangiopathy of children with hemolytic uremic syndrome]. Dis. Candidate of med. Sciences. M., 2014. (in Russian)

24. Many A. et al. Third-trimester unexplained intrauterine fetal death is associated with inherited thrombophilia. Obstetr. and Gynecol. 2002;99:684-687.
25. Kvasnicka J. et al. Prevalence of thrombophilic mutations of FV Leiden, prothrombin G20210A and PAI-1 4G/5G and their combinations in a group of 1450 healthy middle-aged individuals in the Prague and Central Bohemian regions (results of FRET real-time PCR assay). Cas Lek Cesk. 2012;2:76-82. (in Czech).

26. Amitrano L.,Hepatol J. Risk factors and clinical presentation of portal vein thrombosis in patients with liver cirrhosis. 2004; 40:736-741.

27. X. Hu et al. Association Between Plasminogen Activator Inhibitor-1 Genetic Polymorphisms and Stroke Susceptibility, Mol Neurobiol. 2016. Jan 7.

28. Cvetkovic D. Quadruple Vessel Coronary Artery Bypass Grafting in a 14-Year-0ld Child With Plasminogen Activator Inhibitor-1 4G/4G Gene Polymorphism, Semin Cardiothorac Vasc Anesth. 2016;2:163-167. Doi: 10.1177/1089253216631426.

29. L. Ruzzi et al. Association of PLA2 polymorphism of the ITGB3 gene with early fetal loss. Fertil Steril. 2005;2:511-512.

30. Zotova T. et al. The influence of ITGB3 gene polymorphism on the frequency of arterial hypertension in patients with acute coronary syndrome. Klin Med (Mosk). 2013;8:22-24.

31. Vilensky B. Insult: profilaktika, diagnostika i lechenie [Stroke: prevention, diagnosis and treatment]. St.Pb : Foliant, 2002; p. 397 . (in Russian)

\section{Funding}

This research received no specific grant from any funding agency in the public, commercial or not-for-profit sectors.

\section{ORCID and contributionship:}

Mikhail M. Oros - 0000-0003-3182-0493 E, F

Vitaly V. Lutz - 0000-0002-7645-088X B,C,D

Pavlo H. Andrukh - 0000-0002-4929-7832 ${ }^{E}$

Andrii D. Sitkar - 0000-0003-0458-3269 B, C

\section{Conflict of interest statement}

The authors declare that there are no conflicts of interest.

\section{CORRESPONDING AUTHOR Vitaly V. Luts}

Department of Neurology, Mukachevo Central District Hospital

8-13 Pirogova str

Mukachevo, Ukraine

tel: +380506905139

e-mail: lutsvit03@gmail.com

Received: 17.01 .2020

Accepted: 05.03.2020

\footnotetext{
A - Work concept and design, B - Data collection and analysis, C - Responsibility for statistical analysis,
} D-Writing the article, $\mathbf{E}$ - Critical review, $\mathbf{F}$ - Final approval of the article 